\title{
Influence of Nylon on the Tensile Strength of a Polymer Matrix Composite Material
}

\author{
Influencia del nylon en la resistencia a la tensión de un material compuestos de matriz \\ polimérica
}

\author{
Sandra Patricia Romero Nieto ${ }^{1}$, Edwin Salinas Giraldo ${ }^{2}$, \\ Daniel Pedrao $^{3}$, Gary Calderon ${ }^{4}$, Cristian Camilo Castro Valbuena ${ }^{5}$ \\ ${ }^{1}$ Universidad ECCI, Bogotá, Colombia, sromeron@ecci.edu.co \\ ${ }^{2}$ Universidad ECCI, Bogotá, Colombia, xcualquier.cosax@hotmail.com \\ ${ }^{3}$ Universidad ECCI, Bogotá, Colombia, danielpedrao25@hotmail.com \\ ${ }^{4}$ Universidad ECCI, Bogotá, Colombia, gsclb@hotmail.com \\ ${ }^{5}$ Universidad ECCI, Bogotá, Colombia, cristiancastro880515@hotmail.com
}

\begin{abstract}
This work describes the mechanical stress behavior of composite materials made up of a polymer matrix of epoxy resin or polyester resin and reinforcements of: nylon fiber and combinations between fiberglass and nylon fiber. The composite material was evaluated regarding its mechanical stress behavior and its microstructure; results indicate that the highest tensile strength is achieved in the combination using epoxy resin as matrix and nylon fiber as reinforcement. The presence of fiberglass in the material diminishes tensile strength; given that the fiber-matrix interface does not prevail, as evidenced in the microstructural analysis and argued with the chemical bond taking place among the epoxy resin, nylon fiber, and the fiberglass silane. It is, likewise, established that upon increasing the epoxy resin content, mechanical stress strength increases and that said behavior is related with the hydrophilic nature of the fiber and the porosity in the material. Regarding ductility, it was noted that nylon favors slightly the increase of this property in the composite material.
\end{abstract}

Key words: Composites, microstructure, nylon, resin, strength

\section{Resumen}

Este trabajo describe el comportamiento mecánico a la tensión de materiales compuestos conformados por una matriz polimérica de resina epoxi o resina poliéster y refuerzos de: fibra de nylon y combinaciones entre fibra de vidrio y fibra de nylon. El material compuesto se evaluó en cuanto a su comportamiento mecánico a la tensión y su microestructura; los resultados indican que la mayor resistencia a la tensión se logra en la combinación que utiliza como matriz la resina epoxi y como refuerzo la fibra de nylon. La presencia de la fibra de vidrio en el material disminuye la resistencia a la tensión; debido a que no predomina la interface fibra-matriz, como se evidencia en el análisis microestructural y se argumenta con el enlace químico ocurrido entre la resina epoxi, la fibra de nylon y los silanos de la fibra de vidrio; asimismo, se establece que al incrementar el contenido de resina epoxi, aumenta la resistencia mecánica a la tensión y que este comportamiento se relaciona con el carácter hidrofilico de la fibra y la porosidad en el material; en cuanto a la ductilidad se evidenció que el nylon favorece en pequeña medida el aumento de esta propiedad en el material compuesto.

Palabras clave: Compuestos, microestructura, nylon, resina, resistencia 


\section{TECCIENCIA}

\section{Introduction}

Composite materials reinforced with fibers have been the object of constant research due to the combination of properties they present; nylon is a type of fiber useful as reinforcement in composite materials, especially in armor applications of commercial and military vehicles because of its suitable properties of mechanical stress strength, elastic modulus, hardness, capacity to absorb impact energy, thermal stability, and low density [1] The specific properties of nylon are due to its molecular structure, developed during the manufacture process, specifically during the thread spinning process, when the molecular chains aligned, remaining parallel to the axis of the fibers, which increases the material's crystallinity and, consequently, its mechanical strength [2] [3]. Other applications of nylon exist in industry, as in helicopter blades, tire reinforcement, and sporting goods.

For ballistic applications, the thickness or the amount of nylon layers is an indispensable factor and it affects the depth of the impact upon the material [4] [5]. The amount of layers and the thickness of the different materials used in the armor are subjected to diverse ballistic standards established by international entities like the NIJ standard.

Presentation of fibers also provides properties to the composite material; the fiber weaved manages to get the orientation of the stress to be directed both vertically and horizontally, increasing the material's isotropy in its mechanical strength; however, in these intersections of the weaved fiber energy absorption obstacles are created, reducing the rate at which said energy can be dissipated and during ballistic impact phenomena, the weft threads would break before the warp threads [6] [7] [8]; which is why it is recommended to use hybrid panels that increase weave strength and may retard penetration of projectiles into the panel [9].

In Colombia, entities like the Colombian Air Force (FAC) have centered their studies on not only looking for materials that absorb impact energy, but which also have high mechanical strength. This is why ballistic protection systems are designed based on composite materials with ceramic powders, industrial ceramic wastes, resins, and fiberglass to construct a rigid zone in the armor structure with outstanding mechanical properties and sufficient ductility to increase the deformation of the frontal part of the projectile that can impact the material [10]. Because of this, the aim of this research was to study the behavior of the mechanical properties upon stress of composite materials with nylon reinforcements that are impact resistant fibers. Given that a material used as armor should absorb impact energy, it should also adequate mechanical stress strength properties; this work sought to combine reinforcement of nylon fiber with fiberglass to analyze the influence of adding the latter fiber upon the mechanical strength of the material. Addition of fiberglass is done because it is more economic than the nylon fiber; this work also proposed using different matrixes of the composite material as is the case of polyester resin and epoxy resin to analyze which matrix provides the best fiber matrix interface and consequently - the highest mechanical properties and contemplate the possibility of diminishing the amount of nylon layers and, thus, lower the cost of the composite material.

\section{Experimental procedure}

\section{Materials and Methods}

The experimental procedure was developed according to the following two stages: conformation of the composite material and characterization of the composite material.

Conformation of the composite material: five treatments of composite material were manufactured with different matrix and reinforcement proportions according to the design of factor-type experiments shown in Table 1. Epoxy resin and polyester resin were used as matrix and nylon Ep100 and fiberglass as reinforcements in roving presentation

Table 1: composition of the composite material PROPORTIONS OF RESIN AND FIBER USED

\begin{tabular}{|c|c|c|}
\hline \multicolumn{3}{|c|}{ PROPORTIONS OF RESIN AND FIBER USED } \\
\hline Factors & \multicolumn{2}{|c|}{ Levels } \\
\hline & $\%$ Reinforcement & $\%$ Matrix \\
\cline { 2 - 3 } & $41 \%$ pe Nylon & $59 \%$ pe Epoxy \\
\hline $\begin{array}{c}\text { Proportion of } \\
\text { reinforcement } \\
\text { and matrix }\end{array}$ & $\begin{array}{c}23 \% \text { pe Nylon } 42 \% \text { pe } \\
\text { fiberglass }\end{array}$ & $81 \%$ pe Epoxy \\
\cline { 2 - 3 } & $\begin{array}{c}22 \% \text { pe Nylon 22\% pe } \\
\text { fiberglass }\end{array}$ & $56 \%$ pe Epoxy \\
\hline & $\begin{array}{c}22 \% \text { pe Nylon 22\% pe } \\
\text { fiberglass }\end{array}$ & $\begin{array}{c}56 \% \text { pe } \\
\text { Polyester }\end{array}$ \\
\hline
\end{tabular}

The manufacture of the composite material was carried out through manual molding or manual fabrication; curing time was 40 minutes at room temperature.

To verify the amount of matrix to use in the combinations of material, an OHAUS analogue scale was use $d$ with 5-lb capacity.

Characterization of the composite material: Properties of tensile strength 


\section{TECCIENCIA}

The treatments shown in Table 1 were characterized regarding the tensile strength according to the ASTM D7205/7205M-06 standard [11] on Tinius Olsen universal test equipment with a load rate of $10 \mathrm{~mm} / \mathrm{min}$. Tensile tests were conducted in duplicate.

\section{Results}

\subsection{Tensile properties in the composite material}

Figure 1 (a, b, c, d) shows the stress deformation curves of the reinforcement and matrix combinations of the composite material; using as epoxy resin matrix

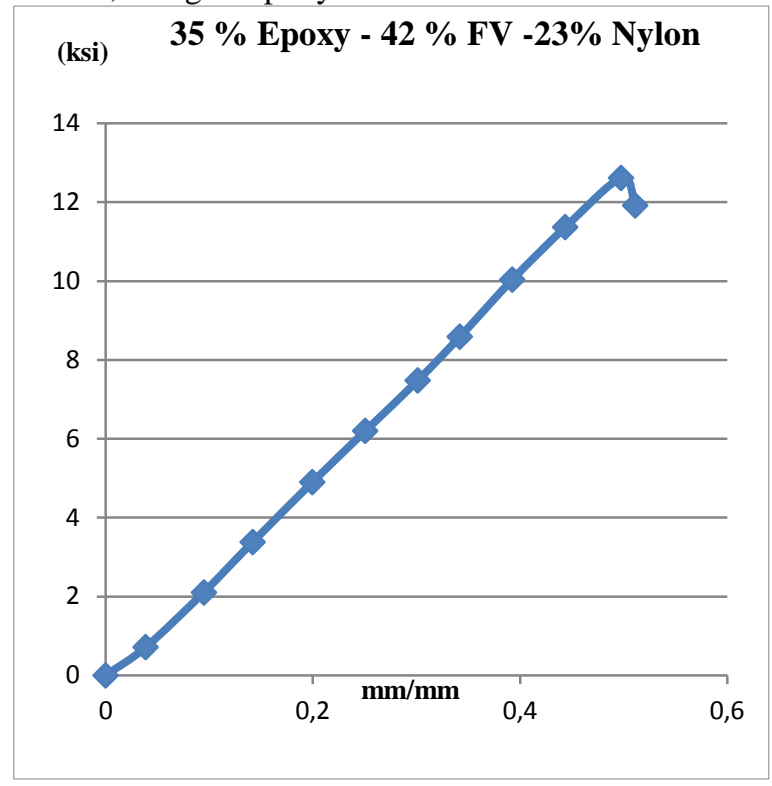

$35 \%$ Epoxy - $42 \%$ Fiberglass $-23 \%$ Nylon

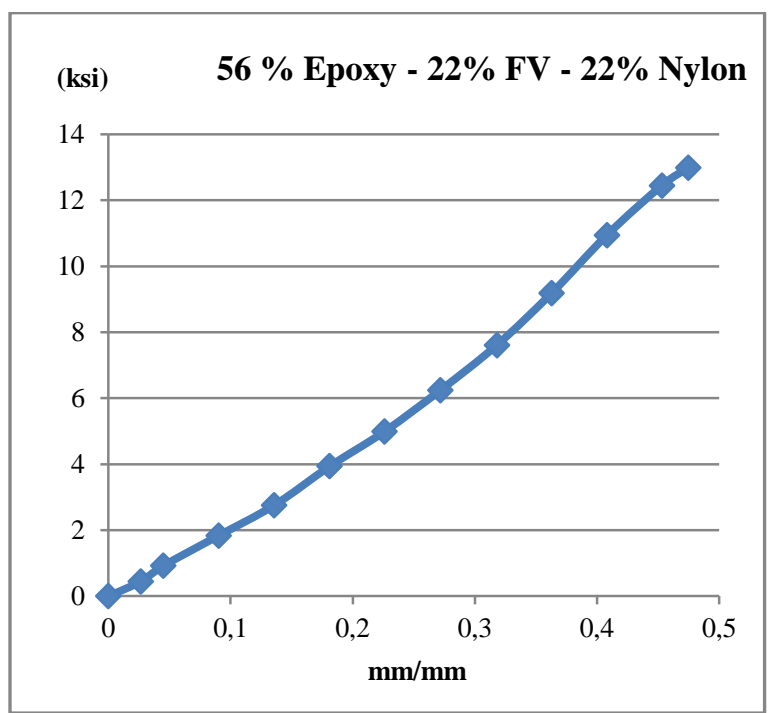

c. $56 \%$ Epoxy - $22 \%$ Fiberglass - $22 \%$ Nylon

\section{Micro-structural analysis}

The microstructure was characterized via scanning electron microscopy (SEM), using a Phenom electronic microscope and $5 \mathrm{KV}$. The test was conducted on the cross-section of the composite material

Figure 1. Stress deformation curves of composite material treatments 


\section{TECCIENCLA}

\subsection{Tensile strength}

Tensile strength results obtained during treatments are shown in Figure 2.

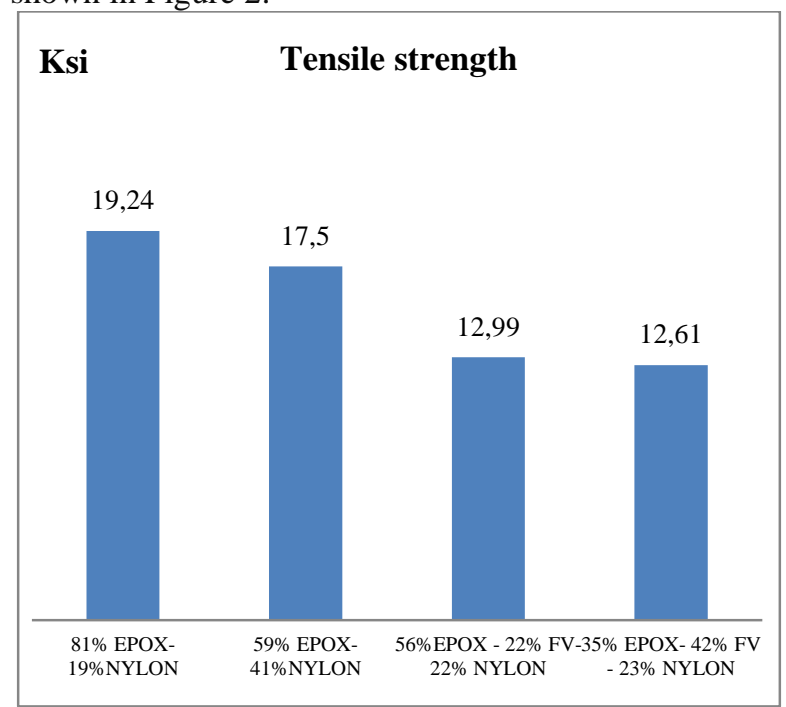

Figure 2. Tensile strength of the composite material Epox: Epoxy resin

\subsection{Ductility}

FV: Fiberglass

Results of ductility in the composite material combinations are shown in Figure 3.

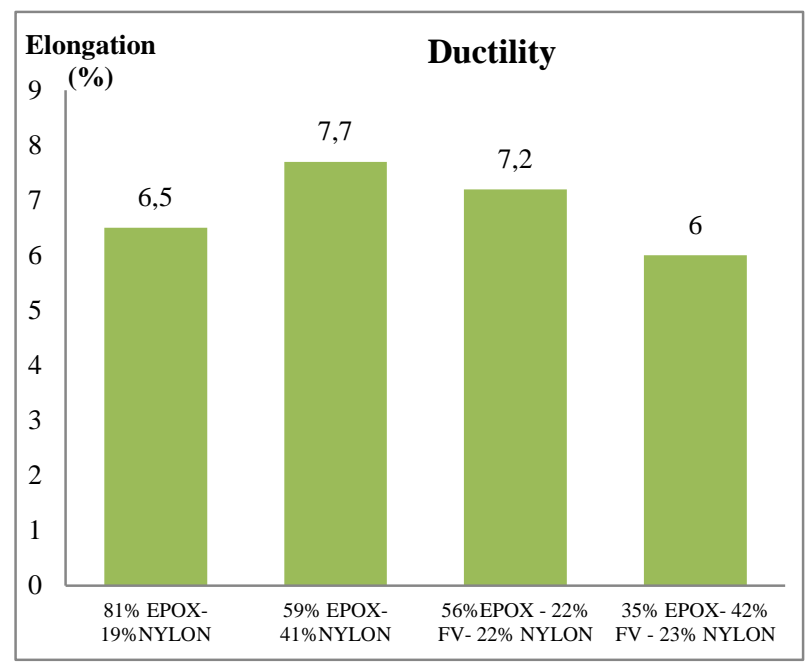

Figure 3. Ductility of the composite material Epox: Epoxy resin FV: Fiberglass

\subsection{Microstructure}

Figure 4 shows SEM images of the microstructures obtained in the composite material consisting of $19 \%$ Nylon and $81 \%$ epoxy resin.

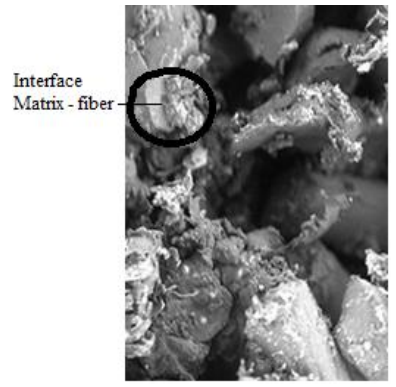

A) $210 x$

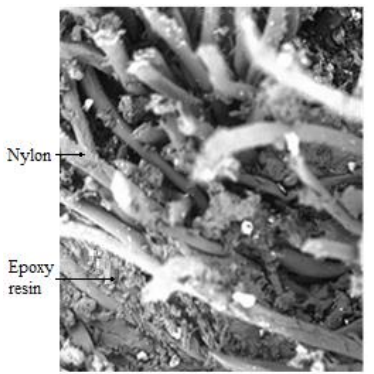

B) $830 \mathrm{X}$
Figure 4. Microstructure of the composite material consisting of $19 \%$ Nylon and $81 \%$ epoxy resin; taken via SEM. a. Detail of matrix fiber interface and $b$. general panorama of the composite material

Figure 5 shows SEM images of the microstructures obtained in the composite material consisting of $41 \%$ Nylon and 59\% epoxy resin.

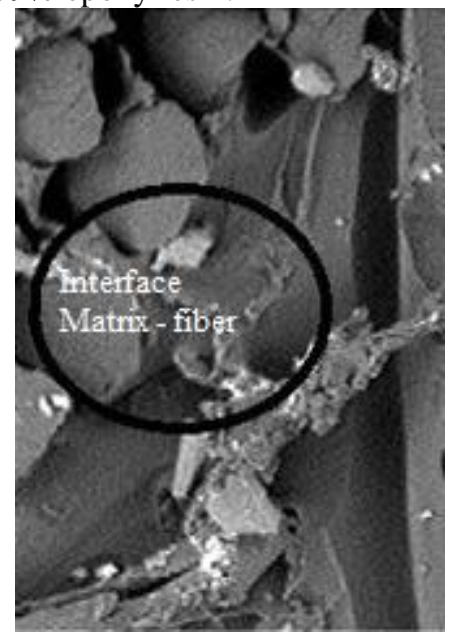

A) Near the resin layer

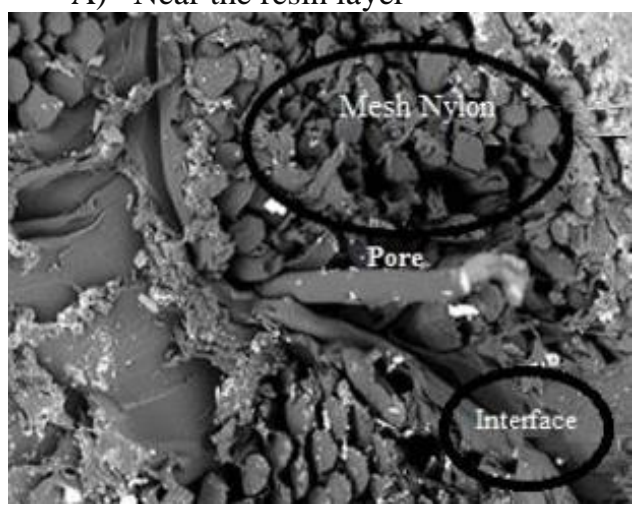

B) General panorama $235 \mathrm{X}$

Figure 5. Microstructure of the composite material consisting of $41 \%$ Nylon and 59\% epoxy resin; taken via SEM. a. Detail of the matrix fiber interface and $b$. general panorama of the composite material. 


\section{TECCIENCIA}

Figure 6 shows SEM images of the microstructures obtained in the composite material consisting of $22 \%$ Nylon, 22\% fiberglass, and 56\% matrix

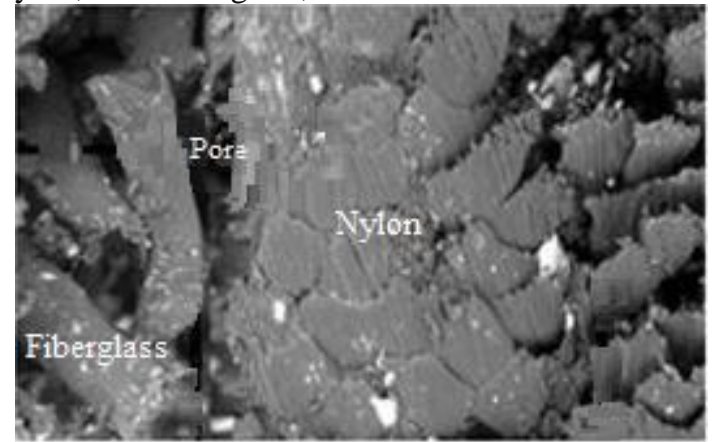

A) Epoxy resin matrix at $215 \mathrm{X}$

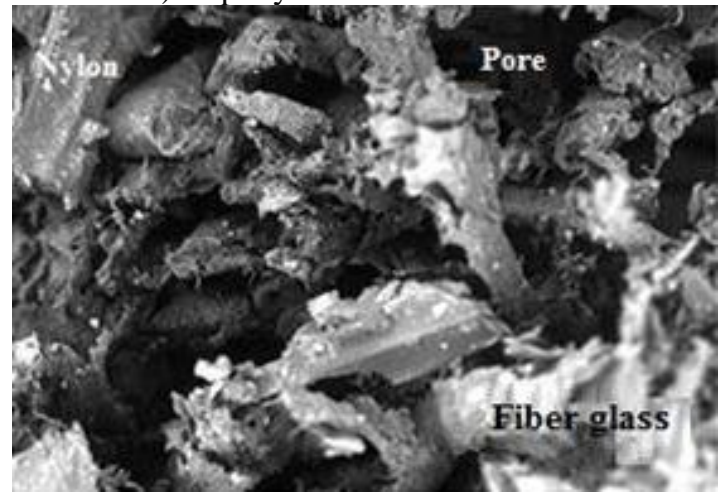

B) Polyester resin matrix at $230 \mathrm{X}$

Figure 6. Composite material microstructure consisting of $22 \%$ Nylon, $22 \%$ fiberglass, and $56 \%$ matrix; taken via SEM

Figure 7 shows the macrostructure of the composite material used as polyester resin matrix.

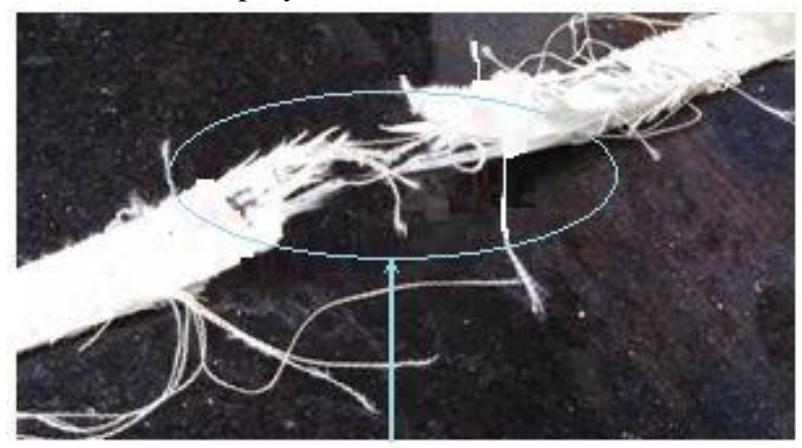

Matrix and fiber are independent

Figure 7. Macrostructure of the composite material used as polyester resin matrix

\section{Discussion}

\section{Properties of tensile strength}

the stress deformation curves shown in figure 1 evidence that the material with epoxy resin as matrix in all its reinforcement combinations presented notable elastic deformation, but did not present considerable plastic deformation; this is because the matrix is fragile and the fiber does not generate a relevant increase in the ductility of the composite material. the material using polyester resin as matrix when subjected to stress loads evidenced separation of the fiber and the matrix, as noted in figure 7 , which caused the material to fail so quickly that it was not possible to gather stress-deformation data; evidencing that between nylon ep 100 and the polyester resin no adequate interface exists, as observed in figure 5 b, generating considerable porosity that also concentrates residual stress and is cause for failure; in this last material, the matrix and the reinforcement act independently and not as composite material.

According to figure 2, the samples composed of nylon and epoxy resin present higher strength to traction than those corresponding to: nylon, fiberglass, and epoxy resin. the increased percentage in weight of the fiberglass diminishes the material's tensile strength; the higher tensile strength of the material using nylon as sole reinforcement is because the interface between nylon and the epoxy resin is better than that presented by fiberglass and the epoxy resin. this difference in the interface is evidenced in the microstructure shown in figure $6 a$.

The interface depends largely on the chemical bond that occurs between the matrix and fiber. Commercial fiberglass has included a treatment with silanes that are elements that permit increasing the humidification of fibers with resin [12] and achieves a chemical bond with the epoxy resin, as shown in figure 8 .

When fiberglass and nylon come into contact with the epoxy resin, the $\mathrm{R}$ functional group of the fiberglass silane binds to a hydroxyl group $(\mathrm{OH})$ from the resin; in turn, an oxygen functional group from nylon binds to the resin's $\mathrm{OH}$ functional group. The bond occurring between the $\mathrm{R}$ functional group from the silanes and the $\mathrm{OH}$ group from the resin must be weaker than that occurring between the $\mathrm{OH}$ group from the resin and the $\mathrm{O}$ group from the nylon; this is why materials using a higher proportion of nylon as reinforcement present higher values of tensile strength, unlike the composite containing both reinforcements (nylon-fiberglass).

From these results, it may be concluded that the system with nylon fiber/epoxy composite materials presents the highest value of tensile strength and the property increases with the number of nylon layers [14].

In composite materials through epoxy resin and nylon, tensile strength has a direct relationship with resin 


\section{TECCIENCIA}

content. This is applied in the range used in this work (81\% epoxy resin - 19\% nylon, and 59\% epoxy resin $41 \%$ nylon). The higher tensile strength presented in the composite material with the highest resin proportion is not due to the mechanical properties of the resin, given that it has lower strength to stress than nylon (strength of the epoxy resin is $15 \mathrm{ksi}$ and that of nylon is $120 \mathrm{ksi}$ ) [12] [15]. Increased tensile strength was due to higher humectation with the greater proportion of resin in the composite material because the nylon fiber is hydrophilic, which is why it absorbs a great amount of resin and if the amount of resin to be used is not sufficient pores are easily generated on the material. These pores become stress concentrators and cause failure, which hinders the fiber-matrix interface [13]. The microstructures of the composite material of epoxy resin at different proportions of nylon fiber are observed in Figures 4 and 5; Figures 4a and 5a show in detail the interface and Figures $4 \mathrm{~b}$ and $5 \mathrm{~b}$ show a general panorama of the material; these last two evidence that the microstructure in the material with the highest proportion of epoxy resin (19\% nylon and 81\% epoxy resin) has greater impregnation of the resin in the biggest part of the material and the presence of the fiber matrix interface; while the in the material with the lowest proportion of resin (41\% nylon and 59\% epoxy resin), the interface is located where it presents the resin layer; but in the extremes where the nylon weave is found no resin diffusion takes place and, consequently, the interface diminishes in this zone; this generates an increase in the porosity content that can be a cause of failure.

The fiber matrix interface between nylon and the epoxy resin also occurs due to the result of the secondary chemical bond between a hydroxyl group from the epoxy resin with an oxygen group from the nylon fiber, as shown in Figure 9.

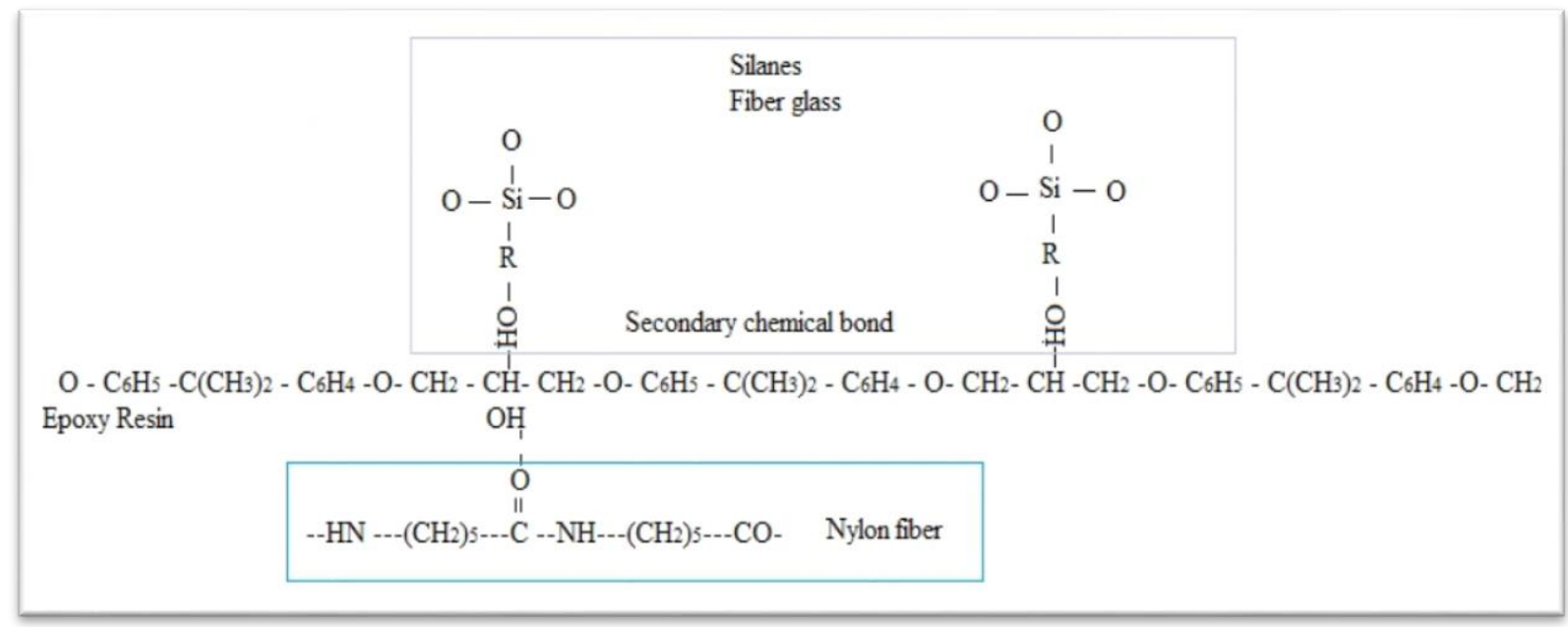

Figure 8. Reaction between the epoxy resin and the fiberglass and nylon fibers Source [13]

\section{O - $\mathrm{C}_{6} \mathrm{H}_{5}-\mathrm{C}(\mathrm{CH} 3)_{2}-\mathrm{C}_{6} \mathrm{H}_{4}-\mathrm{O}-\mathrm{CH}_{2}-\mathrm{CH}-\mathrm{CH}_{2}-\mathrm{O}-\mathrm{C}_{6} \mathrm{H}_{5}-\mathrm{C}(\mathrm{CH} 3)_{2}-\mathrm{C}_{6} \mathrm{H}_{4}-\mathrm{O}-\mathrm{CH}_{2}-\mathrm{CH}-\mathrm{CH}_{2}-\mathrm{O}-\mathrm{CH}_{6} \mathrm{H}_{5}-\mathrm{C}(\mathrm{CH} 3)_{2}-\mathrm{C}_{6} \mathrm{H}_{4}-\mathrm{O}-\mathrm{CH}$ Epoxy Resin $\mathrm{OH}$

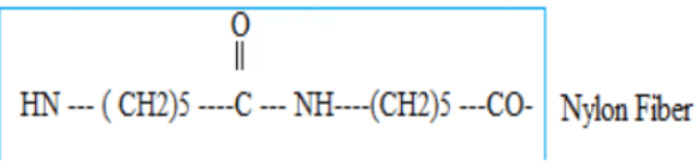

Figure 9. Reaction of epoxy resin and nylon fiber Source: [13] 


\section{Ductility}

Figure 3 shows that the range of ductility in the composite material was elongated between 6 and 7.72\%; the epoxy resin has an elongation percentage of $6 \%$ [12], indicating that both fibers (nylon and fiberglass) provide a slight increase in ductility to the material, with said increase being most pronounced when using the highest proportion of nylon in the material with $59 \%$ epoxy resin - $41 \%$ nylon. Nylon slightly increases the material's ductility and in materials constituted by resins the way to increase their ductility is by modifying the bond for one less rigid that permits movement of polymer chains when conducting a stress effort [12]. That movement of chains is accomplished by the secondary bond occurring between the oxygen from nylon and the $\mathrm{OH}$ group from the epoxy resin, as shown in Figure 8; but said ductility diminishes upon increasing the percentage of fiberglass, as shown in Figure 3 with composite materials of epoxy resin, fiberglass, and nylon fiber.

\section{Conclusions}

The highest tensile strength was obtained by the composite material of epoxy resin reinforced with nylon ep100 (19\% nylon and $81 \%$ epoxy resin). This result was because this combination presented the best fiber matrix interface, which was achieved when using a sufficient proportion of resin, resulting in adequate humectation in the material.

The stress-deformation curves reveal that the material in all its reinforcement matrix combinations presented large elastic deformation, but did not present considerable plastic deformation. This is because by having a fragile matrix, as with epoxy resin, the reinforcement provides a slight increase from 6 to $7.72 \%$ in ductility measured as elongation percentage.

Better stress behavior existed in the composite material using epoxy resin as matrix with respect to that using polyester resin, given that in the latter no adequate fibermatrix interface exists. This generates considerable porosity that acts as concentrator of residual stress and is cause for failure; in this material combination, the matrix and the reinforcement act independently and not as a composite material.

Microstructural analysis reveals that the material with the highest proportion of epoxy resin (19\% nylon and $81 \%$ epoxy resin) has better resin impregnation and presence of the fiber matrix interface; while in the material presenting lower proportion of resin (41\% nylon and $59 \%$ epoxy resin) the interface is localized; but where the nylon weave is present there is no resin diffusion and - consequently - the interface diminishes in this zone, which generates increased porosity content that can be a cause for failure.

Nylon fiber is hydrophilic, which is why it absorbs a considerable amount of resin in the composite material; if resin added in the material is not sufficient, the material will not be completely impregnated with resin and in the sites where said impregnation was not possible no interface will exist. In composite materials through epoxy and nylon resin, tensile strength has a direct relationship with the resin content.

\section{Acknowledgments}

The authors thank Universidad ECCI for its technical support; gratitude is also expressed to CENTIGON COLOMBIA S.A. for providing the material needed for the research.

\section{References}

[1] A. Tejeda-Ochoaa, J. A. Garc y J. A. Bencomo Cisneros, «Characterization of Kevlar-29 fibers by tensile tests and nanoindentation,» Journal of Alloys and Compounds, vol. 536, p. 456-459, 2012.

[2] M. H. Lafitte y A. R. Bunsell, «The fatigue behaviour of Kevlar-29 fibres,» Journal of Materials Science, vol. 17, pp. 2391-2397, 1982

[3] J. Heinecke, «De la fibra a la armadura,» la Tecnología de Aplicación de ley, pp. 80-85, 2007.

[4] M. Karahan, Comparación de la palabra capacidad de absorción de RENDIMIENTO balístico y la Energía de las telas de aramida TEJIDAS y unidireccionales, 2008, pp. 718730 .

[5] «Close focus research. Ballistic standards,» 23 (23/07/2014 09:05 p.m 2014. [En línea]. Available http://www.closefocusresearch.com/ballistic-standards. [Último acceso: 2309 2014].

[6] B. L. Lee, T. F. Walsh, S. T. Won . y H. M. Patts, «Penetration failure mechanisms of armor- grade fiber composites under impact,» J Compos Mate, vol. 35, nº 18, pp. 1605-1633, 2001.

[7] S. Bazhenov, «Energy dissipation portions in the aramid fabric bulletproof,» J Mater Sci, vol. 32, pp. 4167-4173, 1997.

[8] H. I. L Wagner, Lightweight Ballistic Composites: Military and Law-Enforcement Applications, USA: Ashok Batnagar.

[9] O. A. R y H. M. H., «Effect of different construction designs of aramid fabric on the ballistic performances,» Materials and Design, vol. 44, p. 407-413, 2013.

[10] J. Portocarrero y J. Maldonado Villa, «SISTEMAS DE PROTECCIÓN BALÍSTICA BASADOS EN MECANISMOS DE AMARRE DE FIBRA DE VIDRIO,» Asociación Colombiana de Facultades de Ingenería ACOFI, 2013. [En línea]. Available: http://www.acofipapers.org/index.php/acofipapers/2013/paper /view/165. [Último acceso: 2606 2014].

[11] A. International, ASTM D695 : Standard Test Method for Compressive Properties of Rigid Plastics, ASTM, 2008.

[12] V. Vela, M. Cinta y S. Alvarez Blanco, Main commercial polymers, Valencia: Editorial de la UPV. 


\section{TECCIENCIA}

[13] N. R., P. D. K. y N. Muraleedharan, «Development of coir pith/nylon fabric/epoxy hybrid composites: Mechanical and ageing studies,» Materials and Design, vol. 54, p. 644-651, 2014

[14] M. Awaid, K. Abdul, B. A. Abu y K. Noorunnisa, «Chemical resistance, void content and tensile properties of oil palm/jute fiber reinforced polymer hybrid composites,» Mater Des, vol. 32, p. 1014-1019, 2011.

[15] D. Askeland, F. Pradeep y W. Wendelin, The science and engineering of materials, Jefferson City: Global Engineering:, 2010 